\title{
The freshwater decapod crustaceans of Bukit Timah Nature Reserve, Singapore
}

\author{
M. D. Y. Khoo ${ }^{1}$, N. J. L. Tiong ${ }^{1,2}$, T. Li ${ }^{1}$, W. Lim ${ }^{1,3}$, D. J. J. Ng${ }^{1}$, M. Nyanasengeran ${ }^{4}$, \\ D. C. J. $\mathrm{Yeo}^{4} \&$ Y. Cai ${ }^{1}$ \\ ${ }^{1}$ National Biodiversity Centre, National Parks Board, \\ 1 Cluny Road, 259569 Singapore \\ cai_yixiong@nparks.gov.sg \\ ${ }^{2}$ School of Biological Sciences, Nanyang Technological University, \\ 60 Nanyang Drive, 637551, Singapore \\ ${ }^{3}$ Singapore Botanic Gardens, National Parks Board, \\ 1 Cluny Road, 259569 Singapore \\ ${ }^{4}$ Department of Biological Sciences, National University of Singapore, \\ 14 Science Drive 4, 117543 Singapore
}

\begin{abstract}
Freshwater decapod crustaceans serve important ecological functions in tropical stream ecosystems. Stream surveys for decapod crustacean fauna were conducted between February 2015 and April 2016 at nine sites in Bukit Timah Nature Reserve (BTNR). A total of eight species (four freshwater crab, three freshwater shrimp and one crayfish species) out of the nine species known from BTNR were recorded. In general, the species were recorded from sites matching environmental conditions previously known or reported for each species, with some crab species showing minor overlap in their spatial distributions. This highlights the importance of broad-based conservation efforts focusing on the entire stream network in BTNR rather than on specific/selected streams as the various species each appear to have largely unique habitat requirements. The updated information on freshwater decapod crustaceans in BTNR can be used to inform the formulation of conservation and management measures including the establishment of monitoring programs for the protection of our native and threatened aquatic fauna in BTNR.
\end{abstract}

Keywords. Aquatic fauna, freshwater conservation, freshwater crab, freshwater shrimp, freshwater survey, tropical streams

\section{Introduction}

Freshwater decapod crustaceans comprising freshwater crabs, shrimps (a common term used interchangeably with 'prawns'), and crayfish serve important ecological functions. These functions include acting as food sources for predators, mediators of nutrient cycling via facilitating macro-decomposition of leaf litter, influencing primary production, and influencing benthic stream communities (Cai et al., 2007; Esser et al., 2008; Cai et al., 2016). In Singapore, a total of 21 extant native freshwater decapod species (six freshwater crab and 15 freshwater shrimp species), have been recorded (Ng, 1997; Cai et al., 2007; Chua et al., 2015; Cai et al., 2016; Cai, pers. comm.). 
In addition, a further four non-native freshwater decapods (three shrimps and one crayfish) have also been recorded (Yeo, 2010).

Bukit Timah Nature Reserve (BTNR) is situated on Bukit Timah Hill (highest point: $163.63 \mathrm{~m}$ ), and encompasses Singapore's largest remaining patch of continuous primary rainforest (71 ha) (Corlett, 1990). A total of 12 streams and ponds permeate BTNR, together with two quarries on the western and south-western side. These hill streams are typically short and shallow with clear, moderately flowing waters and considerable canopy coverage. They represent a rare sub-type of forest stream found only in BTNR and the nearby hilly areas in central Singapore (Chua et al., 2015; Yeo et al., 2016) and support a large proportion of native and threatened freshwater fauna in Singapore.

The last comprehensive survey of freshwater decapod crustaceans and other aquatic fauna of streams in BTNR was carried out more than two decades ago in the mid-1990s (Ng, 1995, 1997). In the intervening years since, urban and housing developments around the nature reserve, as well as environmental changes, may have resulted in altered hill stream conditions in BTNR, which might have significant impacts on its aquatic biodiversity. Hence, a study to obtain an updated account of the status of freshwater decapod crustaceans in the hill streams in BTNR was initiated. In addition, current and potential threats to the freshwater habitats in this area are identified, as well as recommendations of follow-up actions for freshwater biodiversity conservation and management based on the updated data.

\section{Methods}

Surveys were carried out between February 2015 and April 2016 at nine stream sites (multiple sampling points per site), which also included two ponds. Sampling methods used included push/tray netting by hand at all nine sites and bottle traps at six sites. Push/tray netting at each sampling point involved repetitive sweeping motion against the banks with a tray net $(60 \times 40 \mathrm{~cm})$, starting downstream and moving in an upstream direction along a stretch of 10 metres in the designated sampling spot. Banks and vegetation at the stream edge were disturbed towards the sampling net for up to 30 minutes at each site, and decapod crustaceans caught were kept in a transparent plastic bag containing stream water for measurement and identification. Trapping involved fully submerging three baited plastic minnow/bottle traps in the water per site, with openings facing downstream and retrieval the next day. All decapod crustaceans were identified to species level before being released at their original capture site. The species list thus obtained in this survey was compared against a list of known decapod crustaceans in BTNR consolidated from a literature review. 


\section{Results}

A total of four freshwater crab species, three freshwater shrimp species and one crayfish species were recorded in this study (Table 1). Macrobrachium lanchesteri (Palaemonidae) recorded in the present surveys was not recorded previously $(\mathrm{Ng}$, 1997; Lim, 2012). All species recorded are native to Singapore except Macrobrachium lanchesteri and Cherax quadricarinatus which were restricted to a pond at the edge of BTNR. Macrobrachium malayanum was the most widespread and abundant species and was recorded in eight of the nine sites. Irmengardia johnsoni was the most widespread crab species, and was recorded in five of the nine sites. Johora singaporensis was recorded in a new site on the eastern side of BTNR.

\section{Discussion}

As the last in-depth biodiversity assessment of decapod crustaceans in BTNR was conducted over two decades ago, results from the current survey are useful in addressing gaps in knowledge and making new discoveries. This is exemplified by the discovery of the new site locality for Johora singaporensis (see Li et al., 2015), increasing the total number of stream sites in BTNR for this internationally critically endangered species (Esser et al., 2008) to two. Both sites have known characteristics that support $J$. singaporensis, i.e., hill streams with moderate flow and high levels of dissolved oxygen (Chua et al., 2015; Li et al., 2015). One of our survey sites is the type locality where $J$. singaporensis was first discovered and from where it was described in 1986 (Ng, 1986). J. singaporensis was found to be extirpated at this site by the late 1990s, and was also not recorded during the present survey ( $\mathrm{Ng}$ et al., 2014; Chua et al., 2015; Li et al., 2015). As such, it is important to continue to protect the remaining habitats of $J$. singaporensis, considering that hill streams are rare in Singapore, and that $J$. singaporensis is considered to be an internationally critically endangered species (Esser et al., 2008; Ng et al., 2015; Yeo et al., 2016), and that it has been listed among the world's 100 most threatened species (Baillie \& Butcher, 2012).

Irmengardia johnsoni was the most widespread crab species recorded in this survey (five out of the nine stream sites). The species was observed in high abundance ( $>91$ individuals) in several sites, which suggests that BTNR is a stronghold for this endemic species. The abundance of I. johnsoni in these sites could be due to the low $\mathrm{pH}$ of the water and the thick and muddy streambed, conditions which they are already known to prefer (Chua et al., 2015).

Parathelphusa maculata was recorded in three sites in the periphery of BTNR with elevations not exceeding 50 metres. This is the general habitat preference of Parathelphusa, being a lowland genus, and concurs with previous accounts (Chua et al., 2015).

In general, the three primary freshwater crab species of the families Potamidae and Gecarcinucidae (sensu Yeo et al., 2014) recorded (J. singaporensis, I. johnsoni, and P. maculata) were found to only slightly overlap in their spatial 
Table 1. Freshwater decapod crustaceans recorded from BTNR.

\begin{tabular}{|c|c|c|c|c|}
\hline \# & Species & $\begin{array}{l}\text { Local } \\
\text { conservation } \\
\text { status }^{\wedge}\end{array}$ & $\begin{array}{l}\text { Literature } \\
\text { review }\end{array}$ & $\begin{array}{l}\text { Present } \\
\text { study }\end{array}$ \\
\hline & Family Potamidae & & & \\
\hline 1 & Johora singaporensis Ng, 1986 & Endangered & $\sqrt{ }$ & $\sqrt{ }$ \\
\hline & Family Gecarcinucidae & & & \\
\hline 2 & Irmengardia johnsoni $\mathrm{Ng}$ \& Yang, 1985 & Endangered & $\sqrt{ }$ & $\sqrt{ }$ \\
\hline \multirow[t]{2}{*}{3} & Parathelphusa maculata de Man, 1879 & Not evaluated & $\sqrt{ }$ & $\sqrt{ }$ \\
\hline & Family Sesarmidae & & & \\
\hline 4 & Geosesarma nemesis Ng, 1986 & Endangered & $\sqrt{ }$ & - \\
\hline \multirow[t]{2}{*}{5} & Geosesarma peraccae (Nobili, 1903) & Vulnerable & $\sqrt{ }$ & $\sqrt{ }$ \\
\hline & Family Palaemonidae & & & \\
\hline 6 & Macrobrachium malayanum (Roux, 1934) & Not evaluated & $\sqrt{ }$ & $\sqrt{ }$ \\
\hline \multirow[t]{2}{*}{7} & Macrobrachium lanchesteri (de Man, 1911)* & Not evaluated & - & $\sqrt{ }$ \\
\hline & Family Atyidae & & & \\
\hline \multirow[t]{2}{*}{8} & Caridina johnsoni Cai, Ng \& Choy, 2007 & Not evaluated & - & $\sqrt{ }$ \\
\hline & Family Parastacidae & & & \\
\hline 9 & $\begin{array}{l}\text { Cherax quadricarinatus (von Martens, } \\
1868)^{*}\end{array}$ & Not evaluated & - & $\sqrt{ }$ \\
\hline
\end{tabular}

${ }^{\wedge}$ Status based on Yeo et al. (2008)

\#Literature reviewed: Ong (1965), Ng (1995, 1997), Tan et al. (2017), Lim (2012), Chua et al. (2015)

*Introduced species

distributions, based largely on the habitat characteristics of each stream. This highlights the importance of focusing conservation efforts on the entire stream network in BTNR and not only on selected streams as the various freshwater crabs each have specific habitat requirements.

The sesarmid crab Geosesarma peraccae was recorded in two sites at low abundance (one individual at each site), while Geosesarma nemesis was not recorded in this survey. This was likely because the methods only covered tray net and trap sampling in the streams while both species are semi-terrestrial, hiding in burrows, under rocks and leaf litter in the stream banks $(\mathrm{Ng}, 1988)$. Hence G. peraccae and G. nemesis may have gone undetected at many sites.

The prawn Caridina johnsoni was only distinguished and named little more than a decade ago (Cai et al., 2007) based on material from Sungei Seletar, Lower Peirce reservoir, Nee Soon freshwater swamp forest and Pasir Laba in the western 
catchment of Singapore. Its confirmation from BTNR during the present study is a significant extension of its known distribution within Singapore.

Macrobrachium malayanum is the most abundant and widespread species found in the forest streams of Singapore's nature reserves and tropical Southeast Asia, and it is not surprising that this trend is similar for sites in BTNR $(\mathrm{Ng}, 1997$; Cai et al., 2004; Wowor et al., 2004). This wide distribution is likely due to the wide environmental parameters that $M$. malayanum can tolerate, such as a wide $\mathrm{pH}$ and canopy cover range (Chong \& Khoo, 1987; Cai et al., 2016; Ho et al., 2016).

The introduced Macrobrachium lanchesteri was recorded only at one site at the periphery of BTNR. This is the same site where the introduced Cherax quadricarinatus was observed but not captured during this survey (D. Ng, pers. obs., 2009). As this site is accessible to the public, the presence of these introduced decapod species could be the result of illegal release as is the case for the various introduced ornamental fishes that are also present (see Li et al., 2019). It is important to continue to monitor the population of introduced species within BTNR and ensure that they do not spread to other more sensitive sites with more native biodiversity.

The results of this survey will serve as important baseline data for further studies. The updated information can be used in the formulation of conservation and management measures and the establishment of monitoring programmes for the protection of our native and threatened fauna in BTNR.

\section{References}

Baillie, J.E.M. \& Butcher, E.R. (2012). Priceless or worthless? The world's most threatened species. London, UK: Zoological Society of London.

Cai, Y., Naiyanetr, P. \& Ng, P.K.L. (2004). The freshwater prawns of the genus Macrobrachium Bate, 1868, of Thailand (Crustacea: Decapoda: Palaemonidae). J. Nat. Hist. 38(5): 581-649.

Cai, Y., Ng, P.K.L. \& Choy, S. (2007). Freshwater shrimps of the family Atyidae (Crustacea: Decapoda: Caridea) from Peninsular Malaysia and Singapore. Raffles B. Zool. 55(2): 277-309.

Cai, Y., Li, T.J., Lim, W., Tok, C. \& Woo, C.M. (2016). Biodiversity Assessment of Freshwater Shrimps and Crabs in the Nee Soon Swamp Forest, Singapore. In: Kawai, T, \& Cumberlidge, N. (eds) A global overview of the conservation of freshwater decapod crustaceans, pp. 373-418. Springer International Publishing.

Chong, S.S.C. \& Khoo, H.W. (1987). Macrobrachium malayanum (Roux, 1934) stat. nov. (Decapoda, Palaemonidae) as a synonym of M. geron Holthius, 1950, with notes on its distribution. J. Nat. Hist. 21: 903-913.

Chua, W.J., Ng, J.J.D., Zeng, Y. \& Yeo, D.C.J. (2015). Habitat characteristics of tropical rainforest freshwater crabs (Decapoda: Brachyura: Potamidae, Gecarcinucidae). J. Crust. Biol. 35(4): 53-56.

Corlett, R.T. (1990). Flora and reproductive phenology of the rain forest at Bukit Timah, Singapore. J. Trop. Ecol. 6(1): 55-63. 
Esser, LJ., Cumberlidge, N. \& Yeo, D. (2008). Johora singaporensis (errata version published in 2017). The IUCN Red List of Threatened Species 2008: e.T134219A114582053. Accessed 30 Apr. 2018.

Ho, J., Ramchunder, S., Memory, A., Theng, M., Li, T.J., Clews, E., Cai, Y., Tan, H.H. \& Yeo, D.C.J. (2016). A guide to the freshwater fauna of Nee Soon Swamp Forest. Singapore: Lee Kong Chian Natural History Museum \& Tropical Marine Science Institute, National University of Singapore.

Li., T.J., Lim, W.H. \& Cai, Y. (2015). A new locality of the Singapore Freshwater Crab Johora singaporensis (Crustacea: Brachyura: Potamidae) in the Bukit Timah Nature Reserve. Nat. Singapore 8: 53-56.

Li, T.J,, Loh, Y.X., Lim, W.H, Nyanasengeran, M., Low, B.W., Tan, H.H., Yeo, D.C.J. \& Cai, Y. (2019). The fish fauna of Bukit Timah Nature Reserve, Singapore. Gard. Bull. Singapore 71 (Suppl. 1): 557-573.

Lim, J.Y. (2012). Biodiversity assessment of invertebrates in hill streams at Bukit Timah Nature Reserve. Unpublished B. Sc. Thesis, Nanyang Technological University, Singapore.

Ng, J.J.D., Yeo, D.C.J., Sivasothi, N. \& Ng, P.K.L. (2014). Conservation challenges and action for the Critically Endangered Singapore freshwater crab Johora singaporensis. Oryx 49(2): 345-351.

Ng, J.J.D., McGowan, P.J.K., Raghavan, R., Cai, Y., Cumberlidge, N., Davison, G., Luz, S. \& Yeo, D.C.J. (2015). Conservation Strategy for the Singapore freshwater crab Johora singaporensis. https://www.nparks.gov.sg/ /media/nparks-real-content/ biodiversity/programmes-and-initiatives/conservation_strategy_johora.pdf

Ng, P.K.L. (1986). Preliminary descriptions of 17 new freshwater crabs of the genera Geosesarma, Parathelphusa, Johora and Stoliczia (Crustacea, Decapoda, Brachyura) from South East Asia. J. Singapore Natn. Acad. Sci. 15: 36-44.

Ng, P.K.L. (1988). The freshwater crabs of Peninsular Malaysia and Singapore. Singapore: Shinglee Publishers Pte. Ltd.

Ng, P.K.L. (1995). Freshwater Decapod Crustaceans. Rain Forest in the City: Bukit Timah Nature Reserve, Singapore. Gard. Bull. Singapore (Suppl. 3): 151-157.

Ng, P.K.L. (1997). The Conservation Status of Freshwater Prawns and Crabs in Singapore with Emphasis on the Nature Reserves. Gard. Bull. Singapore 49: 267-272.

Ong, K.M. (1965). A faunal study of a stream on Bukit Timah Hill. Unpublished B.Sc. (Hons.) Thesis, Dept. Zoology, National University of Singapore.

Tan, H.H., Yeo, D.C.J., Low, B.W. \& Nyanasengeran, M. (2017). Fishes, shrimps and aquatic molluscs observed at Singapore Quarry. Singapore Biodivers. Rec. 2017: 7-9.

Wowor, D., Cai, Y. \& Ng, P.K.L. (2004). Crustacea: Decapoda, Caridea. In: Yule, C. M. \& Yong, H. S. (eds.) Freshwater Invertebrates of the Malaysian Region, pp. 337-356. Malaysia: Academy of Sciences of Malaysia.

Yeo, D.C.J. (2010). Introduced decapod crustaceans in Singapore's reservoirs. Cosmos 6(1): 85-100.

Yeo, D.C.J., Tan, S.H. \& Ng, P.K.L. (2008). Horseshoe crabs (Phylum Arthropoda: Subphylum Chelicerata: Class Merostomata) and Decapod Crustaceans (Phylum Arthropoda: Subphylum Crustacea: Order Decapoda). In: Davison, G.W.H., Ng, P.K.L. \& Ho, H.C. (eds) The Singapore Red Data Book: Threatened Plants and Animals of Singapore, $2^{\text {nd }}$ ed., pp. 110-128. Singapore: The Nature Society (Singapore). 
Yeo, D.C.J., Cumberlidge, N. \& Klaus, S. (2014). Preface - freshwater decapod biology in the 21st Century. In: Yeo, D.C.J., Cumberlidge, N. \& Klaus, S. (eds.). Crustaceana Monographs 19: Advances in freshwater decapod systematics and biology, pp. 1-6. Netherlands: Brill Publishers.

Yeo, D.C.J., Luz, S., Cai, Y., Cumberlidge, N., McGowan, P.J.K., Ng, D.J.J., Raghavan, R. \& Davison, G.W.H. (2016). Conservation First: Strategic Planning to Save the Critically Endangered Singapore Freshwater Crab, Johora singaporensis. In: Kawai, $\mathrm{T}$, \& Cumberlidge, N. (eds) A Global Overview of the Conservation of Freshwater Decapod Crustaceans, pp. 359-372. Springer. 